\title{
Comparison of the Fracture Resistance of Hyflex EDM and WaveOne Gold Rotary System Instruments in Abrupt Apical Curvature
}

\author{
Hyflex EDM ve WaveOne Gold Döner Sistem Eğelerinin Ani Apikal \\ Kurvatürde Kırılma Dirençlerinin Karşılaştırılması
}

\section{Cangül KESKİN \\ Uğur İNAN Hande AKGÜN}

\author{
https://orcid.org/0000-0001-8990-4847 \\ https://orcid.org/0000- 0001-8899-2152 \\ https://orcid.org/0000- 0001-7526-4334
}

Ondokuz Mayıs Üniversitesi Diş Hekimliği Fakültesi Endodonti Anabilim Dalı, Samsun

Atıf/Citation: Keskin, C., İnan, U., Akgün, H., (2021). Comparison of the Fracture Resistance of Hyflex EDM and Wave One Gold Rotary System Instruments in Abrupt Apical Curvature. Ege Üniversitesi Diş Hekimliği Fakültesi Dergisi, 42(3), 167-171.

\begin{abstract}
Current developments in restorative dentistry have been recorded theoretically and practically in recent years. Short and long term evaluation in the dental practice in consideration of the developments of conventional knowledge and current studies will ensure the continuity of scientific progress. Regular monitoring of old restorations is very important in terms of evaluating the materials and techniques used in dentistry. As a result of the evaluation of posterior direct composite restorations, it may be decided to repair, retreatment or solely follow the restoration. Correspondingly, the quality of treatment and patient satisfaction will increase. This review aims to make evaluations based on scientific criteria and to be expressed in a universal language.

Objective: This study aimed to compare the cyclic fatigue resistance of Hyflex EDM and WaveOne Gold rotary instruments in simulated abrupt apical curvature at body temperature.

Methods and Materials: A total of 10 Hyflex EDM OneFile (25/04-08) and 10 WaveOne Gold Primary (25/07) instruments free of visible defects were selected after inspection. Instruments were tested in an artificial canal having an angle of curvature of $90^{\circ}$ and a radius of curvature of $2 \mathrm{~mm}$. The instruments were rotated at speed and torque values recommended by manufacturers at $37^{\circ} \mathrm{C}$ until fracture occurred. Time required for fracture (TF) was recorded with a 1/100 s digital chronometer. The TF and fractured fragment length data were statistically analyzed using t-test with significance threshold of $5 \%$.

Results: The mean TF value was $98.40 \pm 19.93$ seconds for WaveOne Gold group and $183.50 \pm 35.33$ seconds for Hyflex EDM group. Hyflex EDM OneFile instruments fractured in a longer time period than WaveOne Gold instruments and the difference between them was statistically significant $(p<0.05)$.

Conclusion: Hyflex EDM OneFile instruments, which are produced with electric discharge machining, were found to be more resistant to cyclic fatigue than WaveOne Gold instruments.
\end{abstract}

Keywords: Temperature, reciprocation, continuous Rotation, cyclic Fatigue

ÖZ

Restoratif dişhekimliğinde son yıllarda teorik ve pratik açıdan güncel gelişmeler kaydedilmiştir. Geleneksel bilgi ve güncel çalışmaların ışı̆̆ında dişhekimliğindeki gelişmelerin kısa ve uzun dönemde değerlendirilmesi bilimsel ilerlemenin sürekliliğini sağlayacaktır. Eski restorasyonların düzenli olarak takip edilmesi dişhekimliğinde kullanılan malzeme ve tekniklerin değerlendirilmesi açısından çok önemlidir. Posterior direkt kompozit restorasyonların değerlendirilmesi sonucu tamir, yenileme veya yalnızca takip kararı verilebilir. Buna bağlı olarak tedavi kalitesi ve hasta memnuniyeti artacaktır. Bu derleme, yapılacak degerlendirmelerin bilimsel kriterlere dayanması ve evrensel dille ifade edilmesini amaçlamaktadır.

Amaç: Bu çalışmanın amacı, Hyflex EDM ve WaveOne Gold döner sistem eğelerin döngüsel yorgunluğa bağlı kırılma dirençlerinin simule ani apikal kurvatürde karşılaştırılmasıdır.

Yöntem: Bu çalıșmada 10 adet Hyflex EDM OneFile (25/04 08) ve 10 adet WaveOne Gold Primary (25/07) eğe kullanıldı. Eğeler kurvatür açıSı $90^{\circ}$, kurvatür yarıçapı $2 \mathrm{~mm}$ olan yapay kanallarda test edildi. Tüm eğeler önerilen hız ve tork değerlerinde $37^{\circ} \mathrm{C}$ sıcaklıkta kırılıncaya kadar kullanıldı. Kırılma zamanı $1 / 100 \mathrm{~s}$ dijital kronometre yardımıyla ölçüldü. Veriler kaydedildi ve \%5'lik anlamlılık eşiği ile bağımsız örneklem t-testi kullanılarak karşılaştııldı.

Bulgular: Kırılıncaya kadar geçen ortalama süre WaveOne Gold grubu için $98.40 \pm 19.93$ ve Hyflex EDM grubu için ise $183.50 \pm 35.33$ saniye olarak bulundu. Hyflex EDM OneFile eğeler, WaveOne Gold Primary eğelere göre daha uzun sürede kırıldı ve aralarındaki fark istatistiksel olarak anlamlı bulundu $(P<0.05)$.

Sonuç: Elektrik boşaltımı ile işleme yöntemi ile üretilen Hyflex EDM NiTi eğeleri, WaveOne Gold eğelerine göre döngüsel yorgunluğa karşı daha dirençli bulundu.

Anahtar Kelimeler: Sıcaklık, Resiprokasyon, Devamlı Rotasyon, Döngüsel Yorgunluk

Sorumlu yazar/Corresponding author*: canglkarabulut@gmail.com

Başvuru Tarihi/Received Date: 17.05.2020

KabulTarihi/Accepted Date: 24.08.2020 


\section{INTRODUCTION}

The introduction of nickel-titanium (NiTi) alloys enabled more favourable and safer root canal preparation due to the superior flexibility and mechanical strength of NiTi compared to stainless-steel hand instruments. ${ }^{1}$ However, separation of $\mathrm{NiTi}$ instruments without a clinically detectable warning is an ongoing problem for endodontic practice. ${ }^{2}$ Disposable use of the NiTi instruments is suggested for prevention of this problem and also cross contamination, however preparation of a molar tooth means that instrument would be used to prepare 3 to 4 root canals. Therefore, evaluation of mechanical properties of motor driven $\mathrm{NiTi}$ instruments is important.

Separation of NiTi instruments occurs via torsional failure, cyclic fatigue and their combination during clinical use. Torsional failure results when the instrument tip is screwed into the canal and its shank continuous to rotate producing a torque value exceeding the plastic limit of the material. ${ }^{3}$ Failure due to cyclic fatigue occurs by continuous stresses of tension and compression in the area of maximum root canal curvature. ${ }^{4}$ Cyclic fatigue resistance of a NiTi instrument depends on numerous factors related to design, kinematics and alloy of the instrument including taper, manufacturing process, cross-sectional shape and type of rotation. ${ }^{5,6}$ Recent studies emphasized that cyclic fatigue testing of an instrument should be conducted under body temperature to simulate clinical use as possible since the instruments show different behaviours under different conditions depending on their phase transformation temperatures. ${ }^{7,8}$

WaveOne Gold (Dentsply Sirona, Ballaigues, Switzerland), which was introduced in 2015, is an upgrade of WaveOne system by maintaining its reciprocating movement while changing the size and cross-sectional shape of the instruments. Moreover, the NiTi alloy underwent thermal treatment after machining, which also contributed to instrument's higher mechanical properties compared to its predecessor. ${ }^{9}$ WaveOne Gold has a primary instrument with $0.25 \mathrm{~mm}$ apical tip diameter and .07 taper. ${ }^{10}$

Hyflex EDM (Coltene/Whaledent, Altstätten, Switzerland) instruments are produced from controlled memory (CM) wires manufactured by electrical discharge machining (EDM) to improve mechanical properties. ${ }^{11}$ The instrument also shows variable crosssectional shapes changing from triangular to rectangular from shaft to tip to optimize flexibility, cyclic and torsional resistance. ${ }^{9}$ Hyflex EDM OneFile has a tip diameter of $0.25 \mathrm{~mm}$ and variable taper from .08 at apical $4 \mathrm{~mm}$ decreasing to .04 along the remaining part. ${ }^{12}$

Root canal anatomy presents challenges for endodontic treatment not only by presenting complex configurations but also showing abrupt curvatures in both mesiodistal and buccolingual directions. ${ }^{13}$ The frequency of abrupt curvatures could be underdiagnosed due to their buccolingual position, angulation of X-ray and superimposition of different canals in preoperative periapical radiographs. Preparation of root canals showing abrupt curvatures might exert great stresses on root canal instruments leading to distortion and failure. ${ }^{14}$ The present study aimed to compare cyclic fatigue resistances of WaveOne Gold Primary and Hyflex EDM OneFile in a simulated abrupt apical curvature at body temperature. The null hypothesis was that there would be no difference between the instruments regarding their cyclic fatigue resistances.

\section{MATERIALS AND METHODS}

A priori sample size calculation was performed by the selection of t-test family (difference between two independent means) using the effect size calculated from a previous study (3.68) by $\mathrm{G}^{*}$ Power 3.1 (Heinrich Heine University, Dusseldorf, Germany) with 0.05 type I error and 0.99 power and resulted that the sample size should be a minimum of 8 instruments. ${ }^{14}$ Therefore, 10 WaveOne Gold Primary (25/07) and 10 Hyflex EDM OneFile (25/04 08) free of visible defects were selected after inspection under magnification using a stereomicroscope (Nikon SMZ 745T, Tokyo, Japan).

A stainless-steel artificial canal with an inner diameter of $1.5 \mathrm{~mm}$ showing an angle of curvature $90^{\circ}$ and radius of curvature of $2 \mathrm{~mm}$ was immersed in a water bath, which temperature was maintained at $37^{\circ} \mathrm{C}$ by a submersible heater and thermostats (Figure 1).

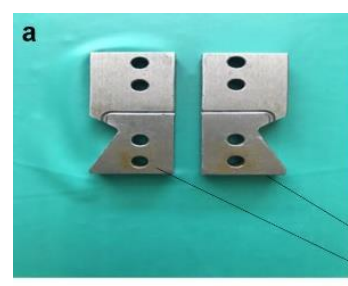

1. Thermostat

2. Thermocouple

3. Submergible heater

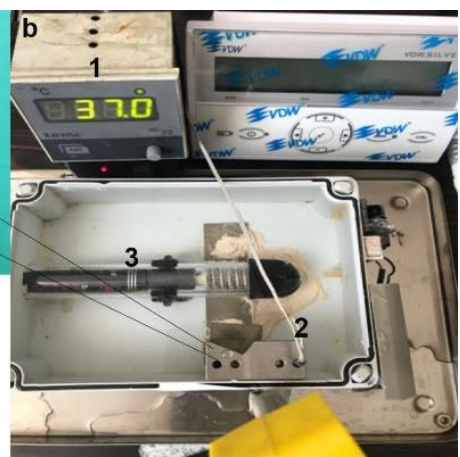

Fig. 1. Artificial canal block with abrupt apical curvature (a) Static cyclic fatigue test device simulating body temperature (b)

WaveOne Gold instruments were operated with VDW Silver endodontic motor (VDW, Munich) using the pre-set "WaveOne ALL" mode, whereas Hyflex EDM OneFile instruments were operated with the device in continuous rotation at $2.5 \mathrm{Ncm}$ torque and $500 \mathrm{rpm}$ speed parameters. All instruments were used until fracture, which was detected both audibly and visually. Time required for fracture (TF) was measured by $1 / 100$ 
seconds chronometer and fractured fragment length was measured by a digital calliper with $10^{-2}$ accuracy. Number of cycles to failure (NCF) values were calculated by multiplying the TF value with recommended speed of each instrument (500 rpm for Hyflex EDM OneFile and $350 \mathrm{rpm}$ for WaveOne Gold) and dividing the result by 60.

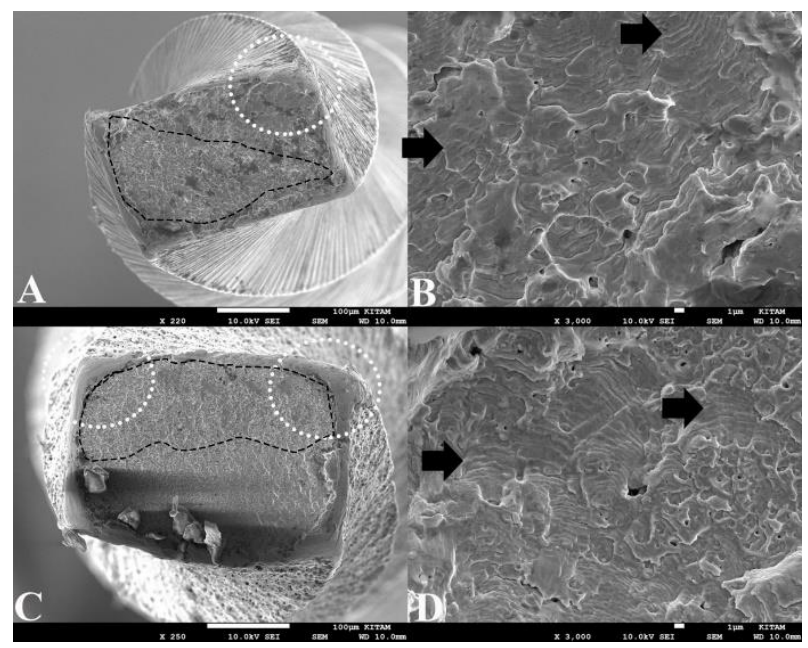

Fig. 2. Scanning electron microscopic images of fractured surfaces of WaveOne Gold Primary (A-B) and Hyflex EDM OneFile (C-D) instruments show typical features of cyclic fatigue failure such as striation marks (arrows) in the 3000x magnification and crack origins (white dotted circles) with fracture zones (black dashed lines) in 200-220x magnifications.

Fractured surfaces of two instruments were visualized with scanning electron microscope (SEM; JEOL JSM7001F; JEOL, Tokyo, Japan), and photomicrographs of the fractured surfaces were obtained at 200-220x and 3000x magnifications (Figure 2).

Since Shapiro-Wilk test revealed that the data showed normal distribution $(P>0.05)$, Student t-test was used to analyse $\mathrm{TF}$ and fragment length data with $5 \%$ significance threshold using SPSS (IBM, SPSS Inc., Chicago, IL, USA). TF data was also analysed using Weibull reliability estimation for the calculation of $99 \%$ survival probability as described in a previous paper. ${ }^{14}$

\section{RESULTS}

Table 1 presents descriptive statistics of TF, NCF and fragment length with Weibull analysis data. Hyflex EDM OneFile instruments showed significantly greater cyclic fatigue resistance than WaveOne Gold Primary instruments $(p<0.05)$. Weibull analysis indicated that Hyflex EDM OneFile instruments also exhibited higher reliability and Weibull modulus than WaveOne Gold Primary.

Table 1. Mean \pm standard deviation values of TF and fractured tip lengths of the tested instruments and Weibull calculations

\begin{tabular}{lccccc}
\hline & TF $(\mathrm{s})$ & NCF & $\begin{array}{c}\text { Weibull } \\
\text { modulus }\end{array}$ & $\begin{array}{c}\text { Predicted TF for } \\
\text { 99\% survival }\end{array}$ & $\begin{array}{c}\text { Fragment length } \\
(\mathrm{mm})\end{array}$ \\
\hline $\begin{array}{l}\text { WaveOne Gold } \\
\text { Primary }\end{array}$ & $98.40 \pm 19.93$ & $574.00 \pm 116.2$ & 4.76 & 40 & $2.84 \pm 0.50$ \\
\hline $\begin{array}{l}\text { Hyflex EDM } \\
\text { OneFile }\end{array}$ & $183.50 \pm 35.33$ & $1529.16 \pm 294.4$ & 4.82 & 76 & $2.62 \pm 0.49$ \\
\hline
\end{tabular}

$\mathrm{TF}$, time required for fracture; $\mathrm{NCF}$, number of cycles to failure

\section{DISCUSSION}

Single file systems have been advocated for preparation of suitable root canals with minimum number of instruments however in an average molar this means preparation of 4 root canals, which might show different curvatures and configurations. An abrupt apical curvature might exert greater stresses on instruments designed for single file systems since a single instrument encounters stresses while enlarging apical, middle and coronal third of root canals. The present study aimed to compare cyclic fatigue resistances of Hyflex EDM OneFile and WaveOne Gold Primary instruments in static cyclic fatigue model using artificial block with an angle of curvature $90^{\circ}$ and radius of curvature of $2 \mathrm{~mm}$. The null hypothesis was rejected due to the higher cyclic fatigue resistance of Hyflex EDM OneFile instruments.
Alloy properties have been reported to influence the cyclic fatigue resistance of NiTi instruments primarily. ${ }^{14}$ Hyflex EDM instruments are manufactured from CM wire that underwent a unique treatment termed electric discharge machining that improves the cutting ability and fatigue resistance, whereas WaveOne Gold instruments are manufactured from Gold wire that received a thermomechanical treatment after machining. ${ }^{9}$ Postmachining thermomechanical treatment of both $\mathrm{CM}$ and Gold wires resulted in a mixed phase which consists mainly of martensite providing increased flexibility and cyclic fatigue resistance. ${ }^{15,16}$ Hyflex EDM instruments have been compared with Gold wire and reported to show superior cyclic fatigue resistance of Hyflex EDM instruments. ${ }^{17}$ Another study, which compared the effect of different working lengths on the cyclic fatigue resistance of Hyflex EDM and WaveOne Gold 
instrument in an abrupt curvature model reported superiority of Hyflex EDM irrespective of working length. ${ }^{18}$ In the present study Hyflex EDM OneFile instruments showed significantly greater fracture resistance and higher reliability than WaveOne Gold when tested in an abrupt curvature. The findings of the present study are in accordance with the findings of the previous ones. ${ }^{17,18}$ On the other hand, another previous study reported similarity between the cyclic fatigue resistance values of Hyflex EDM and WaveOne Gold when tested at $90^{\circ}$ curvature and also superiority of Hyflex EDM over WaveOne Gold when the curvature angle was $45^{\circ} .{ }^{19}$ The differences of the findings might be attributed to the differences in the evaluation methods such as different radius of curvature values and ambient temperature.

The designs of Hyflex EDM OneFile and WaveOne Gold Primary instruments are different apart from their tip diameters. Hyflex EDM OneFile instruments show variable taper between .04 and .08 and different cross sectional shape along their cutting surface changing from triangular near to shaft to quadrangular near the tip, whereas WaveOne Gold instruments have a constant .07 taper and parallelogram cross sectional shape along the cutting surface. ${ }^{10,20}$ Instrument taper, cross sectional shape and area have been regarded to effect cyclic fatigue resistance of NiTi instruments. ${ }^{21,22}$ However it would be difficult to attribute superior cyclic fatigue resistance of Hyflex EDM OneFile to a single variable since the tested instruments showed differences regarding their design and metallurgy. This inability to eliminate the effect of different variables constitutes a major drawback of most laboratory studies. ${ }^{4}$

Movement kinematic has also been considered to influence cyclic fatigue resistance of NiTi

\section{REFERENCES}

1. Shen Y, Zhou HM, Zheng YF, Peng B, Haapasalo M. Current challenges and concepts of the thermomechanical treatment of nickel-titanium instruments. J Endod 2013;39:163-172.

2. McGuigan M, Louca C, Duncan H. Endodontic instrument fracture: causes and prevention. Br Dent $J$ 2013;214:341-348.

3. Martin B, Zelada G, Varela P, Bahillo JG, Magan F, Ahn S, Rodriguez C. Factors influencing the fracture of nickel-titanium rotary instruments. Int Endod $J$ 2003;36:262-266.

4. Cheung GS. Instrument fracture: mechanisms, removal of fragments, and clinical outcomes. Endod Topics 2007;16:1-26. instruments. ${ }^{23,24}$ Reciprocating movement has been developed to prevent screw in effect to improve torsional resistance of instruments, and then it was reported to increase cyclic fatigue resistance also. ${ }^{23,25}$ However, in the present study Hyflex EDM OneFile instrument operated with continuous rotation movement showed significantly greater cyclic fatigue resistance than WaveOne Gold instruments operated with reciprocating motion. Time required for fracture (TF) values are reported to be more clinically relevant and informative for clinicians to express the performance of instruments rather than number of cycles to failure (NCF) values when a reciprocating instrument is compared with an instrument operates with continuous rotation. ${ }^{26,27} \mathrm{NCF}$ values have been associated with the mechanical properties of the instruments, therefore in the present study NCF values were also calculated. ${ }^{28}$ The results of the NCF analysis indicated similarity with TF findings.

The Weibull analysis presents the capacity of tested instruments in extreme-value distribution and the lower values that might be clinically important for operators. ${ }^{29}$ Hyflex EDM OneFile instruments showed a higher Weibull modulus, which is an indicative of a higher reliability of the material. ${ }^{30}$ The lengths of fractured fragments were similar between groups, which indicated the correct position of the instruments within artificial blocks and formation of similar stresses during testing. ${ }^{31}$

\section{CONCLUSIONS}

The comparison of two post-machining thermally treated NiTi instruments exhibited higher cyclic fatigue resistance of Hyflex EDM OneFile, which are produced with EDM than WaveOne Gold Primary instruments.

5. Kitchens GG, Liewehr FR, Moon PC. The effect of operational speed on the fracture of nickel-titanium rotary instruments. J Endod 2007;33:52-54.

6. Ounsi HF, Al-Shalan T, Salameh Z, Grandini S, Ferrari M. Quantitative and qualitative elemental analysis of different nickel-titanium rotary instruments by using scanning electron microscopy and energy dispersive spectroscopy. $J$ Endod 2008;34:53-55.

7. de Vasconcelos RA, Murphy S, Carvalho CAT, Govindjee RG, Peters OA. Evidence for reduced fatigue resistance of contemporary rotary instruments exposed to body temperature. J Endod 2016;42:782-787.

8. Dosanjh A, Paurazas S, Askar M. The effect of temperature on cyclic fatigue of nickel-titanium 
rotary endodontic instruments. J Endod 2017;43:823826.

9. Gavini G, Santos MD, Caldeira CL, Machado MEL, Freire LG, Iglecias EF, Peters OA, Candeiro GTM. Nickel-titanium instruments in endodontics: a concise review of the state of the art. Braz Oral Res 2018;32: e67.

10. WaveOne Gold Brochure, Dentsply Sirona.

Available at:

https://www.dentsply.com/content/dam/dentsply/pi $\mathrm{m}$ /manufacturer/Endodontics/Obturation/Obturators/ Size_Verifiers/WaveOne_Gold_Size_Verifiers/W1 G-Brochure-EN-jb8mf2z-en-1508.pdf, Accessed in 2020 .

11. Iacono F, Pirani C, Generali L, Bolelli G, Sassatelli P, Lusvarghi L, Gandolfi MG, Giorgini L, Prati C. Structural analysis of HyFlex EDM instruments. Int Endod J 2017;50:303-313.

12. Pirani C, Iacono F, Generali L, Sassatelli P, Nucci C, Lusvarghi L, Gandolfi MG, Prati C. HyFlex EDM: superficial features, metallurgical analysis and fatigue resistance of innovative electro discharge machined NiTi rotary instruments. Int Endod $J$ 2016;49:483-493.

13. Plotino G, Grande N, Melo M, Bahia MG, Testarelli L, Gambarini G. Cyclic fatigue of NiTi rotary instruments in a simulated apical abrupt curvature. Int Endod J 2010;43:226-230.

14. Inan U, Keskin C, Yilmaz ÖS, Baș G. Cyclic fatigue of Reciproc Blue and Reciproc instruments exposed to intracanal temperature in simulated severe apical curvature. Clin Oral Invest 2019;23:2077-2082.

15. Hieawy A, Haapasalo M, Zhou H, Wang ZJ, Shen Y Phase transformation behavior and resistance to bending and cyclic fatigue of ProTaper Gold and ProTaper Universal instruments. $J$ Endod 2015;41:1134-1138.

16. Shen Y, Zhou HM, Wang Z, Campbell L, Zheng YF, Haapasalo M. Phase transformation behavior and mechanical properties of thermomechanically treated K3XF nickel-titanium instruments. $J$ Endod 2013;39:919-923.

17. Kaval ME, Capar ID, Ertas H. Evaluation of the cyclic fatigue and torsional resistance of novel nickeltitanium rotary files with various alloy properties. $J$ Endod 2016;42:1840-1843.

18. Azim AA, Tarrosh M, Azim KA, Piasecki L. Comparison between single-file rotary systems: Part 2-The effect of length of the instrument subjected to cyclic loading on cyclic fatigue resistance. $J$ Endod 2018;44:1837-1847.
19. Özyürek T, Gündoğar M, Uslu G, Yılmaz K, Staffoli S, Grande NM, Plotino G, Polimeni A. Cyclic fatigue resistances of Hyflex EDM, WaveOne gold, Reciproc blue and 2shape NiTi rotary files in different artificial canals. Odontology 2018;106:408-413.

20. Pedullà E, Savio FL, Boninelli S, Plotino G, Grande NM, La Rosa G, Rapisarda E. Torsional and cyclic fatigue resistance of a new nickel-titanium instrument manufactured by electrical discharge machining. $J$ Endod 2016;42:156-159.

21. Gao Y, Gutmann JL, Wilkinson K, Maxwell R, Ammon D. Evaluation of the impact of raw materials on the fatigue and mechanical properties of ProFile Vortex rotary instruments. J Endod 2012;38:398-401.

22. Versluis A, Kim HC, Lee W, Kim BM, Lee CJ. Flexural stiffness and stresses in nickel-titanium rotary files for various pitch and cross-sectional geometries. J Endod 2012;38:1399-1403.

23. Castelló-Escrivá R, Alegre-Domingo T, FausMatoses V, Roman-Richon S, Faus-Llacer VJ. In vitro comparison of cyclic fatigue resistance of ProTaper, WaveOne, and Twisted Files. J Endod 2012;38:1521-1524.

24. De-Deus G, Moreira E, Lopes H, Elias C. Extended cyclic fatigue life of F2 ProTaper instruments used in reciprocating movement. Int Endod J 2010;43:10631068.

25. Yared G. Canal preparation using only one Ni-Ti rotary instrument: preliminary observations. Int Endod J 2008;41:339-344.

26. Grande NM, Ahmed HMA, Cohen S, Bukiet F, Plotino G. Current assessment of reciprocation in endodontic preparation: a comprehensive review-part I: historical perspectives and current applications. $J$ Endod 2015;41:1778-1783.

27. Grande NM, Plotino G, Ahmed HMA, Cohen S, Bukiet $F$. The reciprocating movement in endodontics. Endod Prac 2016;9:37-42.

28. Plotino G, Grande NM, Cordaro M, Testarelli L, Gambarini G. A review of cyclic fatigue testing of nickel-titanium rotary instruments. J Endod 2009;35:1469-1476.

29. Weibull W. A statistical distribution function of wide applicability. J Appl Mech 1951;18:293-297.

30. Nguyen HH, Fong H, Paranjpe A, Flake NM, Johnson JD, Peters OA. Evaluation of the resistance to cyclic fatigue among ProTaper Next, ProTaper Universal, and Vortex Blue rotary instruments. J Endod 2014 40,1190-1193. 
31. Topçuoğlu H, Düzgün S, Aktı A, Topçuoğlu G. Laboratory comparison of cyclic fatigue resistance of WaveOne Gold, Reciproc and WaveOne files in canals with a double curvature. Int Endod $J$ 2017;50:713-717. 